\title{
On the functional significance of molecular variation in Symbiodinium, the symbiotic algae of Cnidaria: photosynthetic response to irradiance
}

\author{
A. M. Savage ${ }^{1}$, H. Trapido-Rosenthal ${ }^{2}$, A. E. Douglas ${ }^{1, *}$ \\ ${ }^{1}$ Department of Biology, University of York, York YO10 5YW, United Kingdom \\ ${ }^{2}$ The Biological Station for Research, Ferry Reach, Bermuda GE01
}

\begin{abstract}
The photosynthetic response to irradiance (PI response) of dinoflagellate algae of the genus Symbiodinium was quantified immediately after isolation from symbiosis with 9 species of corals and allied taxa on Bermuda. Significant variation in PI parameters was identified among the algal isolates, but no consistent differences between representatives of different Symbiodinium phylotypes were obtained. In a parallel analysis of Montastraea franksi, a dominant Bermudian coral species, colonies from 4 to $16 \mathrm{~m}$ (all bearing Symbiodinium of Phylotype B) were acclimated to high light conditions. The photoacclimatory response was slight. It included an increase in the dark respiration rate by algae from all collection depths, increased light use efficiency and decreased saturating irradiance of algae from $4 \mathrm{~m}$, and increased maximal photosynthetic rate per unit chlorophyll (chl), but not per cell, for algae from 8 and $16 \mathrm{~m}$. We conclude that generalisations about differences between the photosynthetic traits between Symbiodinium phylotypes are not valid, and that the wide depth distribution of $M$. franksi cannot be attributed to either depth-dependent association with multiple Symbiodinium phylotypes with different photosynthetic properties or strong photoacclimatory capabilities of its complement of Symbiodinium. These data suggest that Symbiodinium phylotype is not generally an important determinant of the abundance and distribution of symbioses on coral reefs.
\end{abstract}

KEY WORDS: Symbiosis $\cdot$ Symbiodinium $\cdot$ Zooxanthellae $\cdot$ PI response $\cdot$ Molecular diversity

\section{INTRODUCTION}

The symbiotic algae in scleractinian corals and other benthic Cnidaria (e.g. sea anemones, gorgonians) on coral reefs photosynthesise at appreciable rates, and much of the photosynthetic carbon fixed by the algae is transferred to the cnidarian tissues, where it is used as a respiratory substrate and for the synthesis of storage lipids and mucus (Trench 1993). This nutritional interaction is widely accepted to be crucial to the persistence and growth of the animals and general 'health' of coral reef ecosystems (Muscatine \& Porter 1977, Muller-Parker \& D'Elia 1997, Knowlton 2001).

${ }^{*}$ Corresponding author. Email: aed2@york.ac.uk
The symbiotic algae in these benthic cnidarians are, almost without exception, dinoflagellates of the genus Symbiodinium. Several species of Symbiodinium have been described based on morphological and biochemical criteria (Blank \& Trench 1986, Trench 1997), and the total molecular diversity among Symbiodinium has been expressed as comparable to the divergence 'between free-living dinoflagellates that are placed in different genera or even orders' (Rowan 1998). Virtually all molecular analyses of this genus have been conducted on rRNA genes and they have revealed that Symbiodinium comprises 2 broad groups; one containing Phylotype A and the other containing Phylotypes B, C and E (also known as D) (Rowan \& Powers 1991a, Rowan \& Knowlton 1995, Wilcox 1998, LaJeunesse 2001). 
The focus of this study is the functional significance of the molecular variation in Symbiodinium. The sequence variation in the rRNA genes of Symbiodinium is widely accepted to be selectively neutral and therefore does not translate directly into phenotypic variation among the Symbiodinim phylotypes. There is, however, persuasive evidence from field observations and experiments that Symbiodinium of different phylotypes exhibit distinctive traits, particularly in their response to temperature and irradiance (Rowan et al. 1997, Baker 2001, Toller et al. 2001a,b): Phylotype A has been described as 'invasive/opportunistic', B as 'sun specialists', C as 'shade specialists', and E as 'stress-tolerant' (Rowan 1998, Toller et al. 2001a). Implicit within these descriptions are 2 key predictions relating to the underlying physiological processes: that: (1) Symbiodinium of different phylotype display consistent differences; and (2) members of each phylotype have very limited acclimatory capabilities.

Relevant data are sparse and not entirely consistent. Variation among Symbiodinium isolates in long-term culture has been identified for photoacclimatory capabilities (Iglesias-Prieto et al. 1994), temperature tolerance (Warner et al. 1999) and production of mycosporine-like amino acids (Banaszak et al. 2000), but only the last appears to differ consistently between phylotypes. The traditional perspective founded on classical terrestrial plant ecophysiology (e.g. Bjorkman 1981), that the photoacclimatory capabilities of the algae contribute to a large depth range of some corals, has been confounded by the realisation that the Symbiodinium cells from different depths may be genetically distinct (Rowan \& Knowlton 1995, Knowlton et al. 1997). Recent investigations include the demonstration that some Symbiodinium of Phylotype A show no detectable photoacclimatory response to depth (Bythell et al. 1997), but that Symbiodinium of Phylotype E acclimated to elevated irradiance display increased tolerance of high temperature (Brown et al. 2001).

The purpose of this study was to explore how Symbiodinium cells of known phylotype vary in their photosynthetic response to irradiance (PI response). This issue is of immediate relevance to both the core symbiotic function of Symbiodinium, photosynthate release to the animal, and to algal tolerance of the key abiotic stressors of high temperature and irradiance. The PI response was quantified from oxygen flux data using Symbiodinium cells immediately after isolation from the symbiosis as the experimental material. This experimental approach has been used successfully in a number of published studies (e.g. Muller-Parker 1984, Masuda et al. 1993, Goiran et al. 1996, Fitt \& Cook 2001) and it ensures that the observed photosynthetic rates are not affected by factors independent of algal genotype, such as animal pigments or self-shading among algal cells in the intact association.

Two experimental designs were used with the objectives: (1) to test whether the PI response of Symbiodinium varied consistently between algae of different phylotypes; and (2) to identify the extent of the photoacclimatory capability of Symbiodinium cells in 1 coral species, namely, Montastraea franksi.

\section{MATERIALS AND METHODS}

Experimental design. The experiments were conducted at the Bermuda Biological Station for Research in summer 1999. All experimental material was allowed to acclimate for at least $2 \mathrm{wk}$ on the laboratory wet bench in running seawater in large fibreglass tanks under natural light conditions (ca. 14:10 h light:dark cycle, maximal mid-day irradiance at the tank surface $1500 \mu \mathrm{mol}$ quanta $\left.\mathrm{m}^{-2} \mathrm{~s}^{-1} \mathrm{PAR}\right)$. The acclimation period was well in excess of the time required for algae, including Symbiodinium, to acclimate to new irradiance conditions (Richardson et al. 1983, Harland \& Davies 1994), and comparison with published data (e.g. Kühl et al. 1995) suggested that the maximum irradiance and total radiation dose were higher than are usually experienced by most symbioses in the field (but see 'Discussion').

The first experiments explored the $P I$ response of Symbiodinium of different phylotypes. Samples of 9 species of animal hosts were collected from shallow reefs and mangrove ponds of depths of up to $6 \mathrm{~m}$ : the scleractinian corals Agaricia sp., Montastraea cavernosa, M. franksi, Oculina diffusa and Porites astreoides; the sea anemones Aiptasia pallida, Bartholomea annulata and Condylactis gigantea; and the jellyfish Cassiopeia xamachana. All animals appeared healthy during the acclimation period and appreciable bleaching was not observed.

The second experiments used colonies of Montastraea franksi collected from depths of 4, 8 and $16 \mathrm{~m}$ and brought to the laboratory in black bags to minimise light exposure. The exact collection sites were not monitored for incident radiation; however, long-term field studies of comparable sites on Bermuda have $90 \%$ of surface irradiance penetrating to $5 \mathrm{~m}, 40 \%$ to $10 \mathrm{~m}$ and $20 \%$ to $15 \mathrm{~m}$ (R. Smith pers. comm.). Half of the colonies from each depth were kept in running seawater in the dark prior to analysis within $24 \mathrm{~h}$ of collection, and the rest were allowed to acclimate for at least $2 \mathrm{wk}$, as above.

Isolation of Symbiodinium cells. Tissue homogenates were obtained by air-brushing (corals) or maceration (anemones and jellyfish) in the defined medium JTB, comprising $420 \mathrm{mM} \mathrm{NaCl}, 26 \mathrm{mM} \mathrm{MgSO}_{4}, 23 \mathrm{mM}$ 
$\mathrm{MgCl}_{2}, 9 \mathrm{mM} \mathrm{KCl}, 9 \mathrm{mM} \mathrm{CaCl} 2,2 \mathrm{mM} \mathrm{NaHCO}{ }_{3}$ 10 mM HEPES, pH 8.2 (Wang \& Douglas 1997). Microscopical analysis (phase contrast $1000 \times$ ) confirmed that this procedure disrupted the animal cells but not the algal cells, and that more than $98 \%$ of the Symbiodinium cells were viable, as assessed with the fluorescein diacetate viability stain for membrane integrity (Sigma). To obtain preparations of isolated Symbiodinium cells, a sample of each homogenate was washed 3 times by centrifugation $(1000 \times g$ for $2 \mathrm{~min})$ followed by gentle resuspension in JTB. The suspensions were free of animal debris and nematocysts detectable by light microscopy $(1000 \times)$, and are referred to as 'freshly-isolated algal preparations'. The algal density in each isolated algal preparation was estimated using a haemocytometer and modified to give a standard final density of $5 \times 10^{5}$ cells ml $^{-1}$ JTB. The preparations were used immediately for analysis of PI response and chlorophyll (chl) extraction.

Photosynthetic response of freshly isolated algal preparations to irradiance. Each algal sample was added to the glass cuvette of a Clarke-type oxygen electrode with an integral polariser and magnetic stirrer (Digital Model 10), for quantification of oxygen flux. The cuvette ( 1 to $2.5 \mathrm{ml}$ variable volume) was maintained at $25 \pm 0.5^{\circ} \mathrm{C}$ by a recirculating water bath, and the electrode was calibrated using sodium hydrosulphite in JTB (0 oxygen) and air-bubbled JTB (saturated oxygen, approximately $203 \mathrm{nmol}_{2} \mathrm{ml}^{-1}$; Goiran et al. 1996). White light of different intensities was provided by a variable-irradiance halogen lamp (HB50) calibrated with a $2 \pi$ quantum light sensor/datalogger (Li-Cor LI-1400). The experiments were conducted in a light-proof room, allowing the algal samples to be exposed to a wide range of accurately measured irradiances between 0 and $1050 \mu \mathrm{mol}$ quanta $\mathrm{m}^{-2} \mathrm{~s}^{-1}$. After a steady dark respiration rate had been achieved, each algal sample was exposed to increasing light intensities, with 6 min at each level. For each value of light intensity, the rate of oxygen production/consumption was quantified for the latter $3 \mathrm{~min}$. At least 6 replicate algal samples (each from a different host individual/ colony) were assayed for each animal species or experimental group.

Oxygen flux was expressed per unit algal number, chl a content and total protein. Using a non-linear regression subroutine in the Excel 97 spreadsheet program, PI curves were fitted iteratively to the data to give the best $\mathrm{R}^{2}$ value using the following equation (e.g. Evans et al. 2000):

$$
P=\left(\frac{\alpha I+P_{\max }-\sqrt{\left(\alpha I+P_{\max }\right)^{2}-4 \alpha \theta I P_{\max }}}{2 \theta}\right)-R
$$

where $P$ is photosynthetic rate, $\alpha$ is light use efficiency, $I$ is photon flux density, $P_{\max }$ is maximum rate of photo- synthesis, $\theta$ is curvature and $R$ is dark respiration rate. This equation does not take into account the photoinhibitory decrease in photosynthesis often observed in algae exposed to high irradiances (Platt et al 1980) and therefore, points on the PI curves which showed inhibition were not included in the curve fitting analysis. Values for $R, \alpha, P_{\max }, I_{\mathrm{c}}$ (compensation light intensity) and $I_{\mathrm{k}}$ (saturation light intensity) were derived from the fitted equation. Values of each parameter for each animal species or experimental group were tested for homogeneity of variance, and the statistical significance of between-group differences was tested using 1-way ANOVA.

Molecular typing of Symbiodinium. DNA was isolated from a sample of each homogenate by the method of Rowan \& Powers (1991b). Briefly, the isolated algae were washed with centrifugation in icecold zooxanthellae isolation buffer (ZIB) $(0.4 \mathrm{M} \mathrm{NaCl}$, $10 \mathrm{mM} \mathrm{Na}_{2}$ EDTA, $20 \mathrm{mM}$ Tris, $8 \mathrm{mM}$ dithiothreitol, $\mathrm{pH}$ 8.2) and then in ice-cold DNA extraction buffer (DNAB) (0.4 M NaCl, $50 \mathrm{mM} \mathrm{Na}_{2}$ EDTA, $\mathrm{pH}$ 8) before an overnight incubation at $50^{\circ} \mathrm{C}$ with $0.5 \mathrm{mg}$ Proteinase $\mathrm{K} \mathrm{ml}^{-1}$ DNAB. The digests were incubated with $1.5 \%$ cetyltrimethylammonium bromide, $1 \mathrm{M}$ $\mathrm{NaCl}, 1.5 \mu \mathrm{g}$ glycogen $\mathrm{ml}^{-1}$ (final concentrations), and DNA was extracted in chloroform and precipitated in ice-cold ethanol with $0.3 \mathrm{M}$ sodium acetate, $\mathrm{pH}$ 6.5. The phylotype of the Symbiodinium was determined by PCR-RFLP analysis of the small subunit rRNA gene. The rDNA fragment was amplified with the 'host-excluding' primers ss3z and ss5z (Rowan \& Powers 1991b), and digested with the diagnostic restriction enzymes TaqI and DpnII (Bythell et al. 1997).

Chlorophyll analysis. A sample of each freshly isolated algal preparation was vacuum-filtered onto a Whatman GF/A glass microfibre filter $(25 \mathrm{~mm}$ in diameter), rinsed with $2 \mathrm{ml}$ ice-cold JTB and brought to dryness with the vacuum. The filter was pounded with $1 \mathrm{ml}$ acetone/DMSO (9:1 v/v) in an ice-cold pestle and mortar. Preliminary tests confirmed that the chl pigments were completely extracted by a 2 -step protocol: (1) incubation for $5 \mathrm{~h}$ in the dark at $4^{\circ} \mathrm{C}$ and collection of the supernatant after centrifugation at $10000 \times g$ for 10 min at $4{ }^{\circ} \mathrm{C}_{i}(2)$ resuspension of the pellet in $1 \mathrm{ml}$ fresh acetone/DMSO by vortexing, followed by overnight incubation and centrifugation $(10000 \times g$ for $10 \mathrm{~min}, 4^{\circ} \mathrm{C}$ ). The total volume of the combined supernatants was measured to the nearest $10 \mu \mathrm{l}$ using accurate micropipettes (Gilson). This solution was centrifuged $\left(10000 \times g\right.$ for $\left.10 \mathrm{~min}, 4^{\circ} \mathrm{C}\right)$ and the absorbance of $1 \mathrm{ml}$ of the supernatant was quantified at 630 and $663 \mathrm{~nm}$ against an acetone/DMSO blank. The concentrations of chls $a$ and $c_{2}$ were calculated using the equations of Jeffrey \& Humphrey (1975). 
Table 1. PI parameters for Symbiodinium preparations from 9 symbioses. Values are mean \pm SE with number of replicates given in parentheses in the first column. The results of 1-way ANOVA tests for variation among host species are shown for each parameter and the superscripted letters indicate homogenous subsets from Tukey's HSD post hoc analyses for each column. Data for $I_{\mathrm{k}}$ and $\alpha$ required square-root transformation before statistical analysis to obtain homogenous variances. Porites astreoides-I and $P$. astreoides-II refer to the algae from 2 groups of $P$. astreoides colonies with distinct PI parameters

\begin{tabular}{|c|c|c|c|}
\hline $\begin{array}{l}\text { (a) } \boldsymbol{P}_{\max }\left(\mathbf{n m o l} \text { oxygen } \mathbf{m i n}^{-\mathbf{1}} \text { ) }\right. \\
\text { Animal species } \\
\text { bearing Symbiodinium }\end{array}$ & $\begin{array}{c}\text { per } 10^{6} \\
\text { Symbiodinium cells }\end{array}$ & $\begin{array}{l}\text { per } \mu g \\
\text { chl } a\end{array}$ & $\begin{array}{l}\text { per } \mu g \\
\text { protein }\end{array}$ \\
\hline \multicolumn{4}{|l|}{ Phylotype A } \\
\hline Bartholomea annulata (6) & $7.53 \pm 0.19^{\mathrm{c}, \mathrm{d}}$ & $1.63 \pm 0.19^{b, c, d}$ & $11.29 \pm 1.90^{\mathrm{b}}$ \\
\hline Cassiopeia xamachana (6) & $10.43 \pm 0.90^{\mathrm{b}, \mathrm{c}}$ & $1.50 \pm 0.06^{\mathrm{b}, \mathrm{c}, \mathrm{d}}$ & $4.92 \pm 0.37^{\mathrm{c}, \mathrm{d}}$ \\
\hline Porites astreoides-I (3) & $20.97 \pm 2.35^{\mathrm{a}}$ & $10.40 \pm 6.53^{\mathrm{a}}$ & $34.92 \pm 8.12^{\mathrm{a}}$ \\
\hline Porites astreoides-II (3) & $7.40 \pm 0.87^{\mathrm{c}, \mathrm{d}}$ & $1.26 \pm 0.10^{\mathrm{c}, \mathrm{d}, \mathrm{e}}$ & $9.21 \pm 1.14^{\mathrm{b}, \mathrm{c}}$ \\
\hline Condylactis gigantea (5) & $5.34 \pm 0.95^{\mathrm{d}}$ & $1.79 \pm 0.31^{\mathrm{b}, \mathrm{c}}$ & $6.15 \pm 2.44^{\mathrm{b}, \mathrm{c}, \mathrm{d}}$ \\
\hline \multicolumn{4}{|l|}{ Phylotype B } \\
\hline Condylactis gigantea (2) & $3.83 \pm 0.75^{\mathrm{d}}$ & $2.24 \pm 0.36^{\mathrm{b}}$ & $4.35 \pm 0.51^{\mathrm{c}, \mathrm{d}}$ \\
\hline Aiptasia pallida (6) & $4.39 \pm 0.26^{\mathrm{d}}$ & $0.93 \pm 0.11^{\mathrm{c}, \mathrm{d}, \mathrm{e}}$ & $4.31 \pm 0.50^{\mathrm{c}, \mathrm{d}}$ \\
\hline Montastraea franksi (6) & $5.97 \pm 0.37^{\mathrm{d}}$ & $1.43 \pm 0.07^{\mathrm{b}, \mathrm{c}, \mathrm{d}}$ & $1.68 \pm 0.06^{\mathrm{d}}$ \\
\hline Oculina diffusa (6) & $4.76 \pm 0.21^{\mathrm{d}}$ & $1.12 \pm 0.14^{\mathrm{c}, \mathrm{d}, \mathrm{e}}$ & $1.96 \pm 0.24^{\mathrm{d}}$ \\
\hline \multicolumn{4}{|l|}{ Phylotype C } \\
\hline Agaricia sp. (6) & $12.42 \pm 1.28^{\mathrm{b}}$ & $0.43 \pm 0.05^{\mathrm{e}}$ & $2.05 \pm 0.39^{\mathrm{d}}$ \\
\hline Montastraea cavernosa (6) & $7.21 \pm 0.58^{\mathrm{c}, \mathrm{d}}$ & $0.73 \pm 0.08^{\mathrm{d}, \mathrm{e}}$ & $0.73 \pm 0.09^{\mathrm{d}}$ \\
\hline ANOVA & $F_{10,46}=41.61, \mathrm{p}<0.001$ & $F_{10,46}=17.56, \mathrm{p}<0.001$ & $F_{10,46}=69.16, \mathrm{p}<0.0$ \\
\hline
\end{tabular}

(b) $R$ (nmol oxygen $\left.\min ^{-1}\right)$

Animal species bearing Symbiodinium

per $10^{6}$ Symbiodinium cells

per $\mu$ chl a

\section{Phylotype A}

Bartholomea annulata (6)

Cassiopeia xamachana (6)

Porites astreoides-I (3)

Porites astreoides-II (3)

Condylactis gigantea (5)

Phylotype B

Condylactis gigantea (2)

Aiptasia pallida (6)

Montastraea franksi (6)

Oculina diffusa (6)

Phylotype C

Agaricia sp. (6)

Montastraea cavernosa (6)

ANOVA

$$
\begin{gathered}
0.59 \pm 0.23^{\mathrm{c}} \\
1.45 \pm 0.23^{\mathrm{b}, \mathrm{c}} \\
6.55 \pm 2.55^{\mathrm{a}} \\
0.82 \pm 0.22^{\mathrm{c}} \\
0.72 \pm 0.25^{\mathrm{c}} \\
\\
0.61 \pm 0.61^{\mathrm{c}} \\
0.74 \pm 0.23^{\mathrm{c}} \\
1.22 \pm 0.18^{\mathrm{b}, \mathrm{c}} \\
0.14 \pm 0.07^{\mathrm{c}} \\
\\
3.44 \pm 0.63^{\mathrm{b}} \\
1.91 \pm 0.25^{\mathrm{b}, \mathrm{c}} \\
F_{10,46}=14.31, \mathrm{p}<0.001
\end{gathered}
$$

$0.13 \pm 0.08^{\mathrm{b}}$

$0.21 \pm 0.03^{b}$

$2.14 \pm 0.79^{\mathrm{a}}$

$0.14 \pm 0.04^{\mathrm{b}}$

$0.23 \pm 0.07^{\mathrm{b}}$

$0.35 \pm 0.35^{\mathrm{b}}$

$0.15 \pm 0.04^{\mathrm{b}}$

$0.29 \pm 0.04^{\mathrm{b}}$

$0.03 \pm 0.02^{\mathrm{b}}$

(c) $\alpha$ (nmol oxygen min $^{-1}$ umol quanta $\mathrm{m}^{-2} \mathrm{~s}^{-1}$ ) Animal species bearing Symbiodinium per $\mu \mathrm{g}$ chl a

$$
\begin{aligned}
& 0.015 \pm 0.004^{\mathrm{b}} \\
& 0.011 \pm 0.001^{\mathrm{b}} \\
& 0.077 \pm 0.030^{\mathrm{a}} \\
& 0.013 \pm 0.001^{\mathrm{b}} \\
& 0.031 \pm 0.009^{\mathrm{b}} \\
& 0.121 \pm 0.057^{\mathrm{a}} \\
& 0.087 \pm 0.060^{\mathrm{a}} \mathrm{b} \\
& 0.009 \pm 0.001^{\mathrm{b}} \\
& 0.007 \pm 0.0011^{\mathrm{b}} \\
& 0.007 \pm 0.001^{\mathrm{b}} \\
& 0.010 \pm 0.003^{\mathrm{b}}
\end{aligned}
$$$$
F_{10,46}=2.97,0.001<\mathrm{p}<0.01
$$$$
F_{10,46}=3.06,0.001<\mathrm{p}<0.01
$$ 
Table 1 (continued)

\begin{tabular}{lcc} 
(d) Compensatory irradiance $\left(\boldsymbol{I}_{\mathrm{c}}\right)$ and saturating irradiance $\left(\boldsymbol{I}_{\mathrm{k}}\right)\left(\boldsymbol{\mu} \mathbf{m o l} \mathbf{q u a n t a} \mathbf{~ m}^{-\mathbf{2}} \mathbf{~}^{-\mathbf{1}}\right)$ & $I_{\mathrm{k}}$ \\
Animal species bearing Symbiodinium & $I_{\mathrm{c}}$ & $134.6 \pm 2.5^{\mathrm{a}, \mathrm{b}}$ \\
\hline Phylotype A & & $161.4 \pm 14.3^{\mathrm{a}}$ \\
Bartholomea annulata (6) & $10.2 \pm 5^{\mathrm{b}, \mathrm{c}}$ & $170.4 \pm 40.4^{\mathrm{a}}$ \\
Cassiopeia Xamachana (6) & $19.3 \pm 2.5^{\mathrm{a}, \mathrm{b}, \mathrm{c}}$ & $190.6 \pm 4.1^{\mathrm{a}, \mathrm{b}}$ \\
Porites astreoides-I (3) & $35.3 \pm 7.3^{\mathrm{a}}$ & $105.4 \pm 38.1^{\mathrm{a}, \mathrm{b}}$ \\
Porites astreoides-II (3) & $11.2 \pm 2.7^{\mathrm{b}, \mathrm{c}}$ & \\
Condylactis gigantea (5) & $16.3 \pm 8.1^{\mathrm{b}, \mathrm{c}}$ & $24.4 \pm 4.8^{\mathrm{b}}$ \\
Phylotype B & & $54.4 \pm 15.7^{\mathrm{b}}$ \\
Condylactis gigantea (2) & $2.4 \pm 2.4^{\mathrm{c}}$ & $199.7 \pm 25.5^{\mathrm{a}}$ \\
Aiptasia pallida (6) & $7.5 \pm 3.0^{\mathrm{b}, \mathrm{c}}$ & $170.2 \pm 10.5^{\mathrm{a}}$ \\
Montastraea franksi (6) & $33.6 \pm 3.4^{\mathrm{a}}$ & $88.5 \pm 19.6^{\mathrm{a}, \mathrm{b}}$ \\
Oculina diffusa (6) & $5.0 \pm 2.4^{\mathrm{b}, \mathrm{c}}$ & $136.4 \pm 26.3^{\mathrm{a}}$ \\
Phylotype C & & $22.0 \pm 4.8^{\mathrm{a}, \mathrm{b}}$ \\
Agaricia sp. (6) & $29.2 \pm 6.1^{\mathrm{a}, \mathrm{b}}$ & $F_{10,46}=2.70,0.01<\mathrm{p}<0.05$ \\
Montastraea Cavernosa (6) & $F_{10,46}=41.61, \mathrm{p}<0.001$ & \\
ANOVA & &
\end{tabular}

Quantification of protein. The protein content of a known volume of each homogenate was quantified using the Bradford reagent (Sigma), following the manufacturer's instructions, with bovine serum albumin dissolved in JTB as protein standard. Algal density in the symbioses was expressed as the number of cells per unit total protein, which approximates to an index of alga:host ratio because the algal protein contributes less than $5 \%$ of the total (unpubl. results). Host surface area was not used as an index of host biomass because it cannot be applied to non-coral hosts and does not take into account variation in coral tissue thickness either between coral species or with depth.

\section{RESULTS}

\section{PI response of Symbiodinium of different phylotypes}

The Symbiodinium cells in the 9 animal species used to test the PI response of Symbiodinium of different phylotypes were assigned by PCR-RFLP analysis to the previously described Phylotypes A, B and C. All samples of 8 species bore a single phylotype: A in Bartholomea annulata, Cassiopeia xamachana and Porites astreoides; B in Aiptasia pallida, Montastraea franksi and Oculina diffusa; and C in Agaricia sp. and Montastraea cavernosa. For the last species, Condylactis gigantea, Phylotype A was detected in 5 individuals, B in 2 and both in 4 . On a per algal cell basis, the chl content varied significantly among animal species for total chl $\left(F_{9,59}=18.00, \mathrm{p}<0.001\right)$, chl a content $\left(F_{9,59}\right.$ $=15.75, \mathrm{p}<0.001)$ and $\mathrm{chl} C_{2}$ content $\left(F_{9,59}=13.57, \mathrm{p}<\right.$ 0.001), but no consistent differences between Symbiodinium of different phylotype were evident. Similarly, the variation in number of Symbiodinium per unit total protein was significant $\left(F_{10,64}=14.71, \mathrm{p}<0.001\right)$, but not correlated with algal phylotype.

The mean PI parameters obtained for the freshly isolated Symbiodinium preparations from each animal species are shown in Table 1 (data for the 4 individuals of Condylactis gigantea bearing mixed infections of Symbiodinium Phylotypes A and B are excluded from the PI analysis). Significant variation in $P I$ parameters was evident (see statistical analysis in Table 1), but inspection of the groupings of the treatments identified by the post hoc tests reveals that PI parameters are: (1) not uniform for all members of 1 phylotype and; (2) not consistently different between phylotypes. Notably, the algae (of Phylotype A) from 3 colonies of Porites astreoides (displayed in Table 1 as Porites astreoides-I) had a significantly higher $P_{\max }$ and $R$ than all other preparations (of all phylotypes) including the other $2 P$. astreoides colonies tested ( $P$. astreoides-II in Table 1). Furthermore, among algae of Phylotype $B$, the preparations from the corals Oculina diffusa and Montastraea franksi had significantly lower light use efficiency $(\alpha)$ per unit algal cell and a significantly higher saturating irradiance $\left(\mathrm{I}_{\mathrm{k}}\right)$ than those from the anemones Aiptasia pallida and Condylactis gigantea. Furthermore, the algal preparations of Phylotypes A and B from Condylactis gigantea differed significantly in $\alpha$ but no other $P I$ parameters $\left(P_{\max }, R, I_{\mathrm{c}}\right.$ or $I_{\mathrm{k}}$ ) calculated.

\section{PI response of Symbiodinium from Montastraea franksi collected from different depths}

Symbiodinium of Phylotype B was the sole alga detected in all samples of Montastraea franksi used for 
$P I$ analysis. The algal density in the coral colonies varied significantly with collection depth, with a significantly higher density in the colonies from $8 \mathrm{~m}$ than those from $4 \mathrm{~m}$ (Fig. 1A). Over the acclimation period, no significant change in algal density was observed. The total chl content per algal cell was significantly lower for coral colonies collected from $4 \mathrm{~m}$ than from 8 and $16 \mathrm{~m}$ and, on acclimation, the corals at 8 and $16 \mathrm{~m}$ (but not $4 \mathrm{~m}$ ) exhibited significant reduction in chl content per algal cell (Fig. 1B). The effect was greater for colonies from 16 than $8 \mathrm{~m}$, and it was paralleled by a slight but unmistakable paling in colour of the coral colonies from $16 \mathrm{~m}$ over the acclimation period.

Analysis of the PI response of the freshly isolated algal preparations (Table 2) revealed that collection depth had no significant impact on $P_{\max }$ and $R_{\text {; how- }}$ ever, algae from colonies at $4 \mathrm{~m}$ had a significantly lower $\alpha$ on a per cell and per unit chl a basis than algae from colonies at 8 and $16 \mathrm{~m}$. The algae from colonies at $4 \mathrm{~m}$ also had a significantly higher value of $\mathrm{I}_{\mathrm{c}}$ than algae from colonies at $16 \mathrm{~m}$ and of $I_{\mathrm{k}}$ than at both 16 and $8 \mathrm{~m}$. Following acclimation, $R$ was elevated for algae from all collection depths, whether expressed per cell or per unit chl $a$. The algae from colonies at $4 \mathrm{~m}$ displayed an increase in $\alpha$ and decrease in $I_{\mathrm{k}}$, in both cases, to values that did not differ significantly from

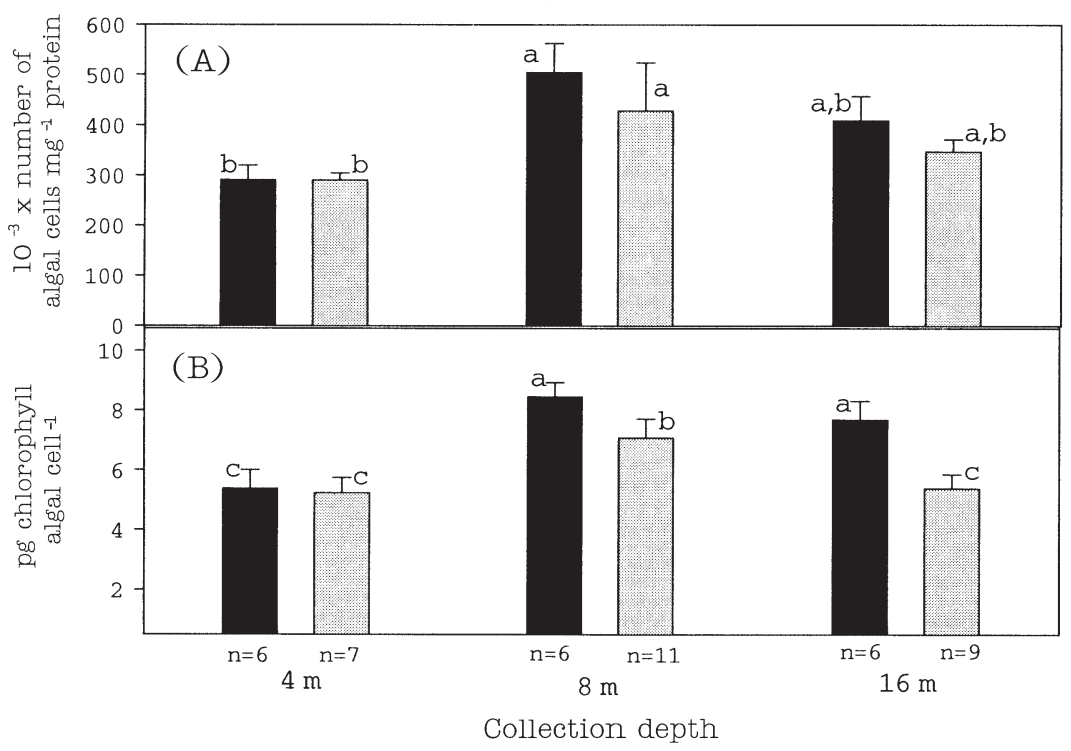

Fig. 1. Response of the algal cells in the coral Montastraea franksi collected from 4, 8 and $16 \mathrm{~m}$, and acclimated for at least $2 \mathrm{wk}$ on the laboratory wet bench. Data are mean \pm SE with number of replicates (n) indicated; closed bars, before acclimation; open bars, after acclimation. (A) Algal density, 2way ANOVA: depth, $F_{2,39}=8.07, \mathrm{p}<0.001$; acclimation, $F_{1,39}=1.51, \mathrm{p}>0.05$; interaction, $F_{1,39}=1.51, \mathrm{p}>0.05$. (B) Chlorophyll content per algal cell, 2 -way ANOVA: depth, $F_{2,39}=26.08, \mathrm{p}<0.001$; acclimation, $F_{1,39}=17.70, \mathrm{p}<0.001$ interaction, $F_{1,39}=5.41,0.001<\mathrm{p}<0.01$. For both (A) and (B), values with the same letters (above each bar) are not significantly different by Tukey's post hoc analysis values for algae from colonies at 8 and $16 \mathrm{~m}$. Moreover, the algae from colonies at 8 and $16 \mathrm{~m}$ displayed an increase in $P_{\max }$ on a per unit chl, but not cell number, basis.

\section{DISCUSSION}

\section{Variation in $P I$ response among freshly isolated preparations of Symbiodinium}

Data obtained in this study suggest that the PI response of Symbiodinium does not map directly onto phylotype. Statistically significant variation in 1 or more PI parameters was obtained within each of the 3 phylotypes, and representatives of no phylotype differed significantly in all PI parameters from any other phylotype (Table 1). Since these data were obtained for material acclimated to uniform conditions, any phylotype-specific patterns should, in principle, have revealed.

There is, however, a caveat to this interpretation: anemone, jellyfish) and the subject of th experiments was freshly isolated algal preparations. As a consequence of variation in animal architecture, animal pigments, carbon dioxide concentrating mechanisms in the intact symbiosis and algal density between host species (e.g. Porter 1976, Fitt et al. 2000, Salih et al. 2001, Leggat et al. 2002), algal cells in the different host species are unlikely to be acclimated to exactly the same light conditions. Detailed inspection of the data provides the basis to assess whether this issue may influence the overall conclusion that the PI response of Symbiodinium does not map onto phylotype. The PI parameters of Phylotype B vary with host architecture (sea anemone vs coral), even though rDNA sequence data suggest that the Symbiodinium cells in the coral Montastraea franksi are more closely related to the algae in the sea anemone Aiptasia pallida than in the coral Oculina diffusa (Savage 2001). Comparison of the PI parameters in Table 1 suggests that the Symbiodinium in the sea anemones $A$. pallida and Condylactis gigantea may have been acclimated to a lower irradiance than those in the corals. The high photosynthetic efficiency $(\alpha)$ and low saturating irradiance $\left(I_{\mathrm{k}}\right)$ of the algae from the sea anemones shows that they 
allocated more resources into light harvesting (Björkman 1981, Falkowski \& Raven 1997). Two factors may have contributed directly to this difference: the significantly higher densities of Symbiodinium in A. pallida and $C$. gigantea ( 0.9 to $1.2 \times 10^{6}$ cells $\mu g^{-1}$ protein) than in $M$. franksi and $O$. diffusa $\left(0.3\right.$ to $0.5 \times 10^{6}{\text { cells } \mu g^{-1}}^{-1}$ protein), potentially resulting in self-shading (Goiran et al. 1996) in the former; and increased light avail- ability in the corals arising from internal reflection from the skeleton (Kühl et al. 1995). However, the link between PI response and host architecture/algal density is not consistent across the full data set. In particular, combining the data for all species, PI parameters and algal density are not correlated, even though both vary significantly with host species. Furthermore, the greatest difference in $P I$ response was obtained for

Table 2. PI parameters for Symbiodinium preparations from Montastraea franksi within 24 h of collection (pre-acclimation) and after incubation on the laboratory wet-bench for at least $2 \mathrm{wk}$ (post-acclimation). All values are mean $\pm \mathrm{SE}(\mathrm{n}=6)$. The results of 2-way ANOVA for each parameter are shown and superscripted letters indicate homogenous subsets from Tukey's HSD post hoc analyses

\begin{tabular}{|c|c|c|c|c|}
\hline \multicolumn{5}{|c|}{ (a) $P_{\max }\left(\mathrm{nmol}\right.$ oxygen $\left.\min ^{-1}\right)$} \\
\hline Collection depth (m) & Before acclimation & After acclimation & Before acclimation & After acclimation \\
\hline 4 & $5.32 \pm 0.39^{\mathrm{a}}$ & $5.97 \pm 0.37^{\mathrm{a}}$ & $1.32 \pm 0.08^{\mathrm{a}}$ & $1.43 \pm 0.07^{\mathrm{a}}$ \\
\hline 8 & $5.89 \pm 0.61^{\mathrm{a}}$ & $6.70 \pm 1.08^{\mathrm{a}}$ & $0.93 \pm 0.10^{\mathrm{b}}$ & $1.40 \pm 0.33^{\mathrm{a}}$ \\
\hline 16 & $5.53 \pm 0.41^{\mathrm{a}}$ & $5.80 \pm 0.45^{\mathrm{a}}$ & $0.88 \pm 0.05^{\mathrm{b}}$ & $1.49 \pm 0.16^{\mathrm{a}}$ \\
\hline \multicolumn{5}{|l|}{ ANOVA } \\
\hline Depth & \multicolumn{2}{|l|}{$F_{2,30}=0.76, \mathrm{p}>0.05$} & \multicolumn{2}{|l|}{$F_{2,30}=1.01, \mathrm{p}>0.05$} \\
\hline Acclimation & \multicolumn{2}{|l|}{$F_{1,30}=1.38, \mathrm{p}>0.05$} & \multicolumn{2}{|c|}{$F_{1,30}=8.87,0.001<\mathrm{p}<0.01$} \\
\hline Interaction & \multicolumn{2}{|l|}{$F_{2,30}=0.11, \mathrm{p}>0.05$} & \multicolumn{2}{|c|}{$F_{2,30}=1.31, \mathrm{p}>0.05$} \\
\hline \multicolumn{5}{|c|}{ (b) $R$ (nmol oxygen $\min ^{-1}$ ) } \\
\hline \multirow[t]{2}{*}{ Collection depth (m) } & \multicolumn{2}{|c|}{ per $10^{6}$ Symbiodinium cells } & \multicolumn{2}{|c|}{ per $\mu \mathrm{g}$ chl $a$} \\
\hline & Before acclimation & After acclimation & Before acclimation & After acclimation \\
\hline 4 & $0.86 \pm 0.18^{b}$ & $1.22 \pm 0.18^{\mathrm{a}}$ & $0.21 \pm 0.05^{\mathrm{b}}$ & $0.29 \pm 0.04^{\mathrm{a}}$ \\
\hline 8 & $0.64 \pm 0.21^{\mathrm{b}}$ & $1.06 \pm 0.26^{\mathrm{a}}$ & $0.10 \pm 0.03$ & $0.29 \pm 0.04^{\mathrm{a}}$ \\
\hline 16 & $0.57 \pm 0.14^{\mathrm{b}}$ & $0.99 \pm 0.33^{\mathrm{a}}$ & $0.09 \pm 0.02^{\mathrm{b}}$ & $0.25 \pm 0.09^{a}$ \\
\hline \multicolumn{5}{|l|}{ ANOVA } \\
\hline Depth & \multicolumn{2}{|l|}{$F_{2,30}=0.69, \mathrm{p}>0.05$} & \multicolumn{2}{|l|}{$F_{2,30}=1.62, \mathrm{p}>0.05$} \\
\hline Acclimation & \multicolumn{2}{|c|}{$F_{1,30}=4.64,0.01<\mathrm{p}<0.05$} & \multicolumn{2}{|c|}{$F_{1,30}=7.05,0.01<p<0.05$} \\
\hline Interaction & \multicolumn{2}{|l|}{$F_{2,30}=0.01, \mathrm{p}>0.05$} & \multicolumn{2}{|l|}{$F_{2,30}=0.30, \mathrm{p}>0.05$} \\
\hline \multicolumn{5}{|c|}{ (c) $\alpha\left(\right.$ nmol oxygen min $^{-1} \mu$ mol quanta $\left.\mathrm{m}^{-2} \mathrm{~s}^{-1}\right)$} \\
\hline \multirow[t]{2}{*}{ Collection depth (m) } & \multicolumn{2}{|c|}{ per $10^{6}$ Symbiodinium cells } & \multicolumn{2}{|c|}{ per $\mu g$ chl a } \\
\hline & Before acclimation & After acclimation & Before acclimation & After acclimation \\
\hline 4 & $0.019 \pm 0.003^{\mathrm{b}}$ & $0.039 \pm 0.005^{\mathrm{a}}$ & $0.005 \pm 0.001^{\mathrm{b}}$ & $0.009 \pm 0.001^{\mathrm{a}}$ \\
\hline 8 & $0.039 \pm 0.008^{\mathrm{a}}$ & $0.035 \pm 0.006^{\mathrm{a}}$ & $0.006 \pm 0.001^{\mathrm{a}}$ & $0.007 \pm 0.002^{\mathrm{a}}$ \\
\hline 16 & $0.048 \pm 0.006^{\mathrm{a}}$ & $0.059 \pm 0.028^{a}$ & $0.008 \pm 0.001^{\mathrm{a}}$ & $0.016 \pm 0.008^{\mathrm{a}}$ \\
\hline \multicolumn{5}{|l|}{ ANOVA } \\
\hline Depth & $F_{2,30}=3.06, \mathrm{p}>0.05$ & & $F_{2,30}=2.77, \mathrm{p}>0.05$ & \\
\hline Acclimation & $F_{1,30}=1.90,0.01<\mathrm{p}$ & & $F_{1,30}=4.47,0.01<\mathrm{p}$ & \\
\hline Interaction & $F_{2,30}=0.97, \mathrm{p}>0.05$ & & $F_{2,30}=1.67, \mathrm{p}>0.05$ & \\
\hline (d) Compensatory irr & e $\left(I_{c}\right)$ and saturating $i$ & iance $\left(I_{\mathrm{k}}\right)(\mu \mathrm{mol} q u$ & $\left.2 \mathbf{s}^{-1}\right)$ & \\
\hline Collection depth (m) & & & & \\
\hline & Before acclimation & After acclimation & Before acclimation & After acclimation \\
\hline 4 & $64.9 \pm 22.3^{\mathrm{a}}$ & $33.6 \pm 3.4^{\mathrm{a}}$ & $381.9 \pm 61.2^{\mathrm{a}}$ & $199.7 \pm 25.5^{b}$ \\
\hline 8 & $21.1 \pm 6.8^{\mathrm{a}}$ & $31.2 \pm 5.0^{\mathrm{a}}$ & $203.8 \pm 38.0^{\mathrm{b}}$ & $232.6 \pm 13.9^{b}$ \\
\hline 16 & $13.5 \pm 3.9^{\mathrm{b}}$ & $14.9 \pm 3.4^{\mathrm{b}}$ & $136.1 \pm 18.3^{\mathrm{b}}$ & $149.5 \pm 34.5^{\mathrm{b}}$ \\
\hline ANOVA & & & & \\
\hline Depth & $F_{2,30}=6.29,0.001<\mathrm{r}$ & 01 & $F_{2,30}=8.70, \mathrm{p}=0.00$ & \\
\hline Acclimation & $F_{1,30}=0.65, \mathrm{p}>0.05$ & & $F_{1,30}=2.60, \mathrm{p}>0.05$ & \\
\hline Interaction & $F_{2,30}=2.35, \mathrm{p}>0.05$ & & $F_{2,30}=5.49,0.001<1$ & .01 \\
\hline
\end{tabular}


members of Phylotype A from a single coral species, Porites astreoides (Table 1). The basis of this intraspecific variation is unknown; all the colonies of $P$. astreoides were collected from the same reef area and depth, bore algal populations at comparable density and chl content (see 'Results'), and did not differ by eye in the intensity of yellow-brown animal pigmentation. The genetic relatedness between the different $P$. astreoides colonies was, however, unknown.

Taken together, these considerations suggest that Symbiodinium vary in their photosynthetic response to irradiance and that the results cannot be attributed exclusively to inter-host differences. Relating to our original objectives (see 'Introduction'), these results indicate that there is no general justification for the description of certain Symbiodinium phylotypes (usually $\mathrm{A}$ and B) as 'sun-loving' and others (notably C) as 'shade-loving' or suited to low light environments.

Of the various patterns observed, the most striking is the combination of high $\alpha$ and $P_{\text {max }}$ displayed by the algae in certain Porites astreoides colonies. A comparable pattern has been obtained for Symbiodinium in some colonies of the shallow-water coral Goniastrea aspera (J. Bythell pers. comm.). This pattern is contrary to the generalisation that high light use efficiency occurs at the expense of investment in carbon fixation, including $P_{\max }$ (Richardson et al. 1983, Evans 1996). However, certain algae, including the dinoflagellates Amphidinium carterae and Peridinium cinctum, acclimated to low light levels have a higher $\alpha$ and $P_{\max }$ than conspecifics acclimated to high light levels (Richardson et al. 1983). It has been suggested that this pattern arises when $P_{\max }$ is limited by photoinhibition at high, but not low, light levels (Richardson et al. 1983).

\section{Acclimatory capability of Symbiodinium from Montastraea franksi}

The Montastraea franksi-Symbiodinium symbioses at depths of 4 to $16 \mathrm{~m}$ differed with respect to both the density and the photosynthetic apparatus of Symbiodinium cells. The significantly lower Symbiodinium density in corals from 4 compared to $8 \mathrm{~m}$ can be interpreted in terms of the costs associated with maintaining a high algal density in high light (shallow) environments where light is not limiting; the costs may include damage from reactive oxygen species produced during photosynthesis (Asada 1996) and nutritional demands on the coral host (Steen 1986). However, not all Symbiodinium symbioses respond to differences in depth in this fashion. There are reports of symbioses in shallow waters with higher (e.g. Titlyanov et al. 1996), lower (e.g. Berner et al. 1987) or comparable (e.g. Falkowski \& Dubinsky 1981, Fitt \& Cook 2001) Sym- biodinium densities to those in deeper waters. Turning to the depth-related differences in the photosynthetic apparatus, algae in shallow-water corals are predicted to have a higher $P_{\max }, I_{\mathrm{c}}$ and $I_{\mathrm{k}}$ and lower $\alpha$ than those in deep-water corals. The data obtained were in broad agreement with these expectations, indicating that, prior to the experimental acclimation, the algae in corals at 8 and $16 \mathrm{~m}$ were acclimated to lower light environments than those at $4 \mathrm{~m}$.

A key concern in any experiment involving transplantation is the possibility that the symbiosis exhibits a non-specific stress response, for example to mechanical damage or change in conditions. Such a response is generally evident within $10 \mathrm{~d}$ and involves loss of algae (Steen \& Muscatine 1987, Hannack et al. 1997, A. M. Savage pers. obs.). Assurance that the responses of the Montastraea franksi colonies transferred from the field to the high irradiance conditions of the laboratory wet bench were not confounded by a generalised stress response comes from the finding that the algal densities in colonies from different depths were maintained during acclimation for at least $14 \mathrm{~d}$. Constant algal densities have also been observed in other studies of photoacclimation (Falkowski \& Dubinsky 1981, Muller-Parker 1985, Harland \& Davies 1994). Significant reduction in the chl content per algal cell was, however, observed for Symbiodinium in colonies from 8 and $16 \mathrm{~m}$, consistent with many published studies of algal responses to increased irradiance (Falkowski \& Dubinsky 1981, Chang et al. 1983, Richardson et al. 1983, Helmuth et al. 1997).

Although alteration in the content of photosynthetic pigments indicated that changes occurred in the photosynthetic machinery of the algae during acclimation to laboratory conditions, there was remarkably little variation in the $P I$ parameters. The principal statistically significant changes comprised respiration $(R)$ in colonies from all depths and increased $P_{\max }$ per $\mu \mathrm{g}$ $\mathrm{chl} a$ in colonies from 8 and $16 \mathrm{~m}$ (correlated with a significant decrease in chl a content of these colonies). Increases in respiration have previously been observed in Symbiodinium acclimated to high light conditions (Muscatine et al. 1984, Porter et al. 1984). In addition, acclimation of the shallow-water $(4 \mathrm{~m})$ colonies resulted in increased $\alpha$ and consequent decrease in $I_{\mathrm{k}}$, a response very similar to that described for Symbiodinium from the corals Pocillopora verucosa and Pavona praetorta (Richardson et al. 1983). The change in $\alpha$ may have resulted from rearrangement of the photosynthetic components on the thylakoid membranes, which enhances the efficiency of electron transport, or changes in the light harvesting activity of accessory pigments (which were not measured here). These results were contrary to expectation because they are indicative of a photoacclimatory response to a 
'lower' light environment, even though the midday irradiance during acclimation regularly exceeded $1000 \mu \mathrm{mol}$ quanta $\mathrm{m}^{-2} \mathrm{~s}^{-1}$, considerably higher than the averaged irradiance at $4 \mathrm{~m}$. One possible explanation for the apparently paradoxical result is that the field irradiance may be enhanced by a process roughly analogous to sunflecks penetrating a forest canopy: ripples on the surface water may concentrate light such that irradiance of up to $4000 \mu \mathrm{mol}$ quanta $\mathrm{m}^{-2} \mathrm{~s}^{-1}$ are reached at points on the shallow reefs (IglesiasPrieto \& Trench 1994, Lesser et al. 2000).

The most important aspect of these results, however, is the small scale of the variation in PI parameters between Symbiodinium from corals at 4 and $16 \mathrm{~m}$ and the minimal responses to transplantation to the high light environment of the laboratory wet bench. Two factors that may have contributed to these results are a very limited photoacclimatory capability of Symbiodinium and less variation of the light environment within the corals than of the external light environment. The latter can be achieved by coral-mediated photoacclimation, for example through modification of the concentration and composition of pigments that either screen the algae from excessive light or enhance photon capture at low light intensities (e.g. Muller-Parker 1984, Lesser \& Shick 1989, Masuda et al. 1993, Salih et al. 2001), through extension/retraction of the polyps (e.g. Muller-Parker 1984, Day 1994) and, in the long term, by modified growth patterns resulting in changing polyp density or overall colony morphology (Porter et al. 1984, Helmuth et al. 1997). Consistent with an important contribution of the host to photoacclimation, Symbiodinium cells in long-term culture exhibit a greater photoacclimatory capability than Symbiodinium freshly isolated from the symbiosis (MullerParker 1984). This observation is consistent with an important impact of the host on photoacclimation.

The dominant Symbiodinium in Montastraea franksi on Bermuda is Phylotype B, but Phylotypes A, B, C and $E$ have all been detected in this coral species in the Caribbean (Savage 2001, Toller et al. 2001a). Our demonstration in this study of no consistent interphylotype differences in the PI responses of Symbiodinium cells indicates that it would be premature to interpret the low specificity of the symbiosis in the Caribbean as an indication of greater functional variation in the algae in this coral in the Caribbean than on Bermuda.

\section{CONCLUDING COMMENTS}

Strands in the literature on the photosynthetic response of Symbiodinium in corals and allied animals offer the perspective that these symbioses colonise a wide range of photic environments either through the photoacclimatory responses of Symbiodinium (Iglesias-Prieto et al. 1994) or by hosting multiple alternative Symbiodinium genotypes with different photosynthetic properties (e.g. Rowan et al. 1997, Baker 2001). This study illustrates that such a perspective may not encompass the full complexity or diversity of symbioses. First, the photosynthetic characteristics of Symbiodinium cannot be deduced reliably from the usual current method, molecular typing of the rRNA genes, and consequently, it is not valid to make generalisations about the photosynthetic traits of different phylotypes. Second, the success of at least 1 coral species, Montastraea franksi, a dominant species over a wide range of depths around Bermuda, is not dependent on photoacclimation by its complement of Symbiodinium.

It is widely recognised that the benefit a host gains from its complement of symbionts may vary among symbiont genotypes and with environmental circumstance (Douglas 1998). However, the distribution and abundance of a host species on a reef is likely to be influenced by many more factors than simply the genotype of Symbiodinium that it contains.

Acknowledgements. We thank Drs. Owen Atkin and John Bythell for advice on oxygen flux analysis, and the Natural Environment Research Council for financial support. This is contribution number 1625 from the Bermuda Biological Station for Research.

\section{LITERATURE CITED}

Asada K (1996) Radical production and scavenging in the chloroplasts. In: Baker NR (ed) Advances in photosynthesis, Vol 5. Kluwer Academic Publishers, Dordrecht, p 123-150

Baker AC (2001) Reef corals bleach to survive change. Nature 411:765-766

Banaszak AT, LaJeunesse TC, Trench RK (2000) The synthesis of mycosporine-like amino acids (MAAs) by cultured, symbiotic dinoflagellates. J Exp Mar Biol Ecol 249: 219-233

Berner T, Achituv Y, Dubinsky Z, Benayahu Y (1987) Pattern of distribution and adaptation to different irradiance levels of zooxanthellae in the soft coral Litophyton arboreum (Octocorallia: Alcyonacea). Symbiosis 3:23-40

Bjorkman O (1981) Responses to different quantum flux densities. In: Lange OL, Nobel PS, Osmond CB, Ziegler H (eds) Encyclopaedia of plant physiology, Vol 12A. SpringerVerlag, Amsterdam, p 57-107

Blank RJ, Trench RK (1986) Nomenclature of endosymbiotic dinoflagellates. Taxon 35:286-294

Brown BE, Dunne RP, Goodson MS, Douglas AE (2001) Marine ecology - bleaching patterns in reef corals. Nature 404:142-143

Bythell J, Douglas AE, Sharp VA, Searle JB, Brown BE (1997) Algal genotype and photoacclimatory responses of the symbiotic algae Symbiodinium in natural populations of the sea anemone Anemonia viridis. Proc R Soc Lond Ser B $264: 1277-1282$ 
Chang SS, Prezelin BB, Trench RK (1983) Mechanisms of photoadaptation in three strains of the symbiotic dinoflagellate Symbiodinium microadriaticum. Mar Biol 76:219-229

Day RJ (1994) Algal symbiosis in Bunodeopsis: sea anemones with 'auxilliary' structures. Biol Bull 186:182-194

Douglas AE (1998) Host benefit and the evolution of specialization in symbiosis. Heredity 80:599-603

Evans JR (1996) Developmental constraints on photosynthesis: effects of light and nutrition. In: Baker NR (ed) Advances in photosynthesis, Vol 5. Kluwer Academic Publishers, Dordrecht, p 281-304

Evans JR, Schortemeyer M, McFarlane N, Atkin OK (2000) Photosynthetic characteristics of 10 Acacia species grown under ambient and elevated atmospheric $\mathrm{CO}_{2}$. Aust $\mathrm{J}$ Plant Physiol 27:13-25

Falkowski PG, Dubinsky Z (1981) Light-shade adaptation of Stylophora pistillata, a hermatypic coral from the Gulf of Eilat. Nature 289:172-174

Falkowski PG, Raven JA (1997) Aquatic photosynthesis. Blackwell Scientific Publications, Maldon, MA

Fitt WK, Cook CB (2001) Photoacclimation and the effect of symbiotic environment on the photosynthetic response of symbiotic dinoflagellates in the tropical marine hydroid Myrionema amboinense. J Exp Mar Biol Ecol 256:15-31

Fitt WK, McFarland FK, Warner ME, Chilcoat GC (2000) Seasonal patterns of tissue biomass and densities of symbiotic dinoflagellates in reef corals and relation to coral bleaching. Limnol Oceanogr 45:677-685

Goiran C, Al-Moghrabi S, Allemand D, Jaubert J (1996) Inorganic carbon uptake for photosynthesis by the symbiotic coral/dinoflagellate association. I. Photosynthetic performances of symbionts and dependence on sea water bicarbonate. J Exp Mar Biol Ecol 199:207-225

Hannack K, Kestler P, Sicken O, Westheide W (1997) The influence of UV radiation on number and ultrastructure of the endosymbiotic dinoflagellates in the sea anemone Cereus pedunculataus (Anthozoa: Actiniaria). Helgol Meeresunters 51:487-502

Harland AD, Davies P (1994) Time-course of photoadaptation in the symbiotic sea anemone Anemonia viridis. Mar Biol 119:45-51

Helmuth BST, Timmerman BEH, Sebens KP (1997) Interplay of host morphology and symbiont microhabitat in coral aggregations. Mar Biol 130:1-10

Iglesias-Prieto R, Trench RK (1994) Acclimation and adaptation to irradiance in symbiotic dinoflagellates. I. Responses of the photosynthetic unit to changes in photon flux density. Mar Ecol Prog Ser 113:163-175

Jeffrey SW, Humphrey GF (1975) New spectrophotometric equations of determining chlorophylls $a, b, c_{1}$ and $c_{2}$ in higher plants, algae and natural phytoplankton. Biochem Physiol Pflanz 167:191-194

Knowlton N (2001) The future of coral reefs. Proc Natl Acad Sci USA 98:5419-5425

Knowlton N, Mate JL, Guzman HM, Rowan R, Jara J (1997) Direct evidence for reproductive isolation among the three species of the Montastraea annularis complex in Central America (Panama and Honduras). Mar Biol 127:705-711

Kühl M, Cohen Y, Dalsdaard T, Jørgensen BB, Revsbech NP (1995) Microenvironment and photosynthesis of zooxanthellae in scleractinian corals studied with microsensors for $\mathrm{O}_{2}, \mathrm{pH}$ and light. Mar Ecol Prog Ser 117:159-172

LaJeunesse TC (2001) Investigating the biodiversity, ecology, and phylogeny of endosymbiotic dinoflagellates in the genus Symbiodinium using the ITS region: in search of a 'species' level marker. J Phycol 37:866-880

Leggat W, Marendy EM, Baillie B, Whitney SM, Ludwig M,
Badger MR, Yellowlees D (2002) Dinoflagellate symbioses: strategies and adaptations for the acquisition and fixation of inorganic carbon. Funct Plant Biol 29:309-322

Lesser MP, Shick JM (1989) Effects of irradiance and ultraviolet radiation on photoadaptation in the zooxanthellae of Aiptasia pallida: primary production, photoinhibition, and enzyme defenses against oxygen toxicity. Mar Biol 102: 243-255

Lesser MP, Mazel C, Phinney D, Yentsch CS (2000) Light absorption and utilization by colonies of the congeneric hermatypic corals Montastraea faveolata and Montastraea cavernosa. Limnol Oceanogr 45:76-86

Masuda K, Goto M, Maruyama T, Miyachi S (1993) Adaptation of solitary corals and their zooxanthellae to low light and UV radiation. Mar Biol 117:685-691

Muller-Parker G (1984) Photosynthesis-irradiance responses and photosynthetic periodicity in the sea anemone Aiptasia pulchella and its zooxanthellae. Mar Biol 82:225-232

Muller-Parker G (1985) Effect of feeding regime and irradiance on the photophysiology of the symbiotic sea anemone Aiptasia pulchella. Mar Biol 90:65-74

Muller-Parker G, D'Elia CF (1997) Interactions between corals and their symbiotic algae. In: Birkeland C (ed) Life and death of coral reefs. Chapman \& Hall, New York, p 96-113

Muscatine L, Porter JW (1977) Reef corals: mutualistic symbioses adapted to nutrient-poor environments. Bioscience $27: 454-460$

Muscatine L, Falkowski PG, Porter JW, Dubinsky Z (1984) Fate of photosynthetically fixed carbon in light- and shade-adapted colonies of the symbiotic coral Stylophora pistillata. Proc R Soc Lond Ser B 222:181-202

Platt T, Gallegos CL, Harrison WG (1980) Photoinhibition of photosynthesis in natural assemblages of marine phytoplankton. J Mar Res 38:687-701

Porter JW (1976) Autotrophy, heterotrophy and resource partitioning in Caribbean reef-building corals. Am Nat 110: 731-742

Porter JW, Muscatine L, Dubinsky Z, Falkowski PG (1984) Primary production and photoadaptation in light- and shadeadapted colonies of the symbiotic coral Stylophora pistillata. Proc R Soc Lond Ser B 222:161-180

Richardson K, Beardall J, Raven JA (1983) Adaptation of unicellular algae to irradiance: an analysis of strategies. New Phytol 93:157-191

Rowan R (1998) Diversity and ecology of zooxanthellae on coral reefs. J Phycol 34:407-417

Rowan R, Knowlton N (1995) Intraspecific diversity and ecological zonation in coral-algal symbiosis. Proc Natl Acad Sci USA 92:2850-2853

Rowan R, Powers DA (1991a) A molecular genetic classification of zooxanthellae and the evolution of animal-algal symbioses. Science 251:1348-1351

Rowan R, Powers DA (1991b) The molecular genetic identification of symbiotic dinoflagellates (zooxanthellae). Mar Ecol Prog Ser 71:65-73

Rowan R, Knowlton N, Baker AC, Jara J (1997) Landscape ecology of algal symbionts creates variation in episodes of coral bleaching. Nature 388:265-269

Salih A, Larkum AWD, Cox G, Kühl M, Hoegh-Guldberg O (2000) Fluorescent pigments in corals are photoprotective. Nature 408:850-853

Savage AM (2001) Genetic diversity and photosynthetic characteristics of Zooxanthellae Symbiodinium. PhD thesis, University of York

Steen RG (1986) Evidence for heterotrophy by zooxanthellae in symbiosis with Aiptasia pulchella. Biol Bull 170:267-278 
Steen RG, Muscatine L (1987) Low temperature evokes rapid exocytosis of symbiotic algae by a sea anemone. Biol Bull 172:246-263

Titlyanov EA, Titlyanova TV, Leletkin VA, Tsukahara J, Van Woesik R, Yamazato K (1986) Degradation of zooxanthellae and regulation of their density in hermatypic corals. Mar Ecol Prog Ser 139:167-178

Toller WW, Rowan R, Knowlton N (2001a) Zooxanthellae of the Montastraea annularis species complex: patterns of distribution of four taxa of Symbiodinium on different reefs and across depths. Biol Bull 201:348-359

Toller WW, Rowan R, Knowlton N (2001b) Repopulation of zooxanthellae in the Caribbean corals Montastraea annularis and $M$. faveolata following experimental and disease-associated bleaching. Biol Bull 201:360-373

Editorial responsibility: Otto Kinne (Editor),

Oldendorf/Luhe, Germany
Trench RK (1993) Microalgal-invertebrate symbioses: a review. Endocytobiol Cell Res 9:135-175

Trench RK (1997) Diversity of symbiotic dinoflagellates and the evolution of microalgal-invertebrate symbioses. Proc 8th Int Coral Reef Symp 2:1275-1286

Wang JT, Douglas AE (1997) Nutrients, signals, and photosynthate release by symbiotic algae. Plant Physiol 114: 631-636

Warner ME, Fitt WK, Schmidt GW (1999) Damage to Photosystem II in symbiotic dinoflagellates: a determinant of coral bleaching. Proc Natl Acad Sci USA 96: $8007-8012$

Wilcox TP (1998) Large-subunit ribosomal RNA systematics of symbiotic dinoflagellates: morphology does not recapitulate phylogeny. Mol Phylogenet Evol 10:436-448

Submitted: April 25, 2001; Accepted: August 26, 2002

Proofs received from author(s): November 4, 2002 